\title{
Pengolahan Limbah Cair Tahu Sebagai Energi Alternatif Biogas yang ramah lingkungan
}

\author{
Kemas Ridhuan \\ Jurusan Teknik Mesin, Fakultas Teknik, Univ. Muh Metro \\ Jl. Ki Hajar Dewantara no 115 Metro \\ kmsridhuan@yahoo.co.id
}

\begin{abstract}
Abstrak
Cairan limbah tahu merupakan komponen yang berbahaya jika dibuang begitu saja ke lingkungan karena dapat menimbulkan bau busuk, penyakit dan mencemari air, juga pemicu gas rumah kaca. Maka limbah tersebut perlu diolah sebagai energi alternative biogas. Penelitian ini bertujuan untuk mengetahui cara pengolahan limbah cair tesebut, banyak biogas yang dapat dihasilkan, lama waktu permentasi dan konstruksi reactornya. Metode penelitian ini yaitu pembuatan alat reaktor dan pengujiannya. Reaktor biogas terdiri dari tampungan utama limbah cair tahu dan tampungan biogas. saluran masuk dan keluar limbah, juga saluran keluar biogas. Proses fermentasi berlangsung pada kondisi anaerob yaitu proses pada kondisi tanpa oksigen. Prinsip Kerja Reaktor yaitu limbah cair tahu dimasukkan ke dalam reaktor yang kedap udara, memanfaatkan proses pencernaan yang dilakukan oleh bakteri methanogen yang produknya berupa gas methana $(\mathrm{CH} 4)$. Proses fermentasi berlangsung selama 28 hari dengan hasil sebagai berikut dari 97 liter limbah cair tahu yang diolah maka didapat biogas sejumlah $0,0564 \mathrm{~m}^{3}$ atau 56,4 liter biogas.
\end{abstract}

Kata kunci : Limbah tahu, biogas, anaerobik, energi.

\section{Pendahuluan}

Sebagian besar industri tahu tempe masih merupakan industri kecil skala rumah tangga yang tidak dilengkapi dengan unit pengolah air limbah, sedangkan industri tahu dan tempe yang dikelola koperasi beberapa diantaranya telah memiliki unit pengolah limbah. Dengan sistem pengolah limbah yang ada, maka limbah yang dibuang ke peraian kadar zat organiknya (BOD) masih cukup tinggi yaitu sekitar $400-1400 \quad \mathrm{mg} / \mathrm{l}$ (Damayanti,2004). Untuk itu perlu dilakukan proses pengolahan lanjut agar kandungan zat organik di dalan air limbah memenuhi standar air buangan yang boleh dibuang ke saluran umum.
Proses produksi tahu menghasilkan 2 jenis limbah, limbah padat dan limbah cairan. Pada umumnya, limbah padat dimanfaatkan sebagai pakan ternak, sedangkan limbah cair dibuang langsung ke lingkungan. Limbah cair pabrik tahu ini memiliki kandungan senyawa organik yang tinggi. Tanpa proses penanganan dengan baik, limbah tahu menyebabkan dampak negatif seperti polusi air, sumber penyakit, bau tidak sedap, meningkatkan pertumbuhan nyamuk, dan menurunkan estetika lingkungan sekitar (Rahayu, 2009).

Banyak pabrik tahu skala rumah tangga di Indonesia tidak memiliki proses pengolahan limbah cair. Ketidakinginan pemilik pabrik tahu untuk mengolah limbah cairnya 
disebabkan karena kompleks dan tidak efisiennya proses pengolahan limbah, ditambah lagi tidak menghasilkan nilai tambah. Padahal, limbah cair pabrik tahu memiliki kandungan senyawa organik tinggi yang memiliki potensi untuk menghasilkan biogas melalui proses an-aerobik. Pada umumnya, biogas mengandung 50-80\% metana, $\mathrm{CO} 2, \mathrm{H} 2 \mathrm{~S}$ dan sedikit air, yang bisa dijadikan sebagai pengganti minyak tanah atau LPG (BBPT,1997). Dengan mengkonversi limbah cair pabrik tahu menjadi biogas, pemilik pabrik tahu tidak hanya berkontribusi dalam menjaga lingkungan tetapi juga meningkatkan pendapatannya dengan mengurangi konsumsi bahan bakar pada proses pembuatan tahu.

Sebagian besar limbah cair yang dihasilkan oleh industri pembuatan tahu adalah cairan kental yang terpisah dari gumpalan tahu yang disebut air dadih. Cairan ini mengandung kadar protein yang tinggi dan dapat segera terurai. Limbah cair ini sering dibuang secara langsung tanpa pengolahan terlebih dahulu sehingga menyebabkan terjadinya pencemaran air, seperti warna sungai menjadi keruh dan menghasilkan bau busuk dan mencemari sungai. Sumber limbah cair lainnya berasal dari pencucian kedelai, pencucian peralatan proses, pencucian lantai dan pemasakan serta larutan bekas rendaman kedelai. Jumlah limbah cair yang dihasilkan oleh industri pembuat tahu kira-kira 15-20 1/kg bahan baku kedelai, sedangkan bahan pencemarnya kira-kira untuk TSS sebesar $30 \mathrm{~kg} / \mathrm{kg}$ bahan baku kedelai, BOD $65 \mathrm{~g} / \mathrm{kg}$ bahan baku kedelai dan COD $130 \mathrm{~g} / \mathrm{kg}$ bahan baku kedelai (EMDI \& bapedal, 1994).

Karakter limbah cair yang
dihasilkan berupa bahan organik padatan tersuspensi (kulit, selaput lendir dan bahan organik lain). Industri pembuatan tahu dan tempe harus berhati-hati dalam program kebersihan pabrik dan pemeliharaan peralatan yang baik karena secara langsung hal tersebut dapat mengurangi kandungan bahan protein dan organik yang terbawa dalam limbah cair.

Industri pengolahan tahu tersebut selain menghasilkan produk utama berupa tahu dalam berbagai bentuk (tahu putih, tahu goreng, tahu pong, dan kerupuk tahu), juga menghasilkan limbah padat maupun limbah cair. Limbah padat sudah banyak dimanfaatkan seperti pakan ternak dan tempe gembus. Namun limbah cair belum dimanfaatkan sama sekali atau langsung dibuang begitu saja ke perairan. Akibatnya perairan menjadi tercemar, begitu pula dengan simpanan air tanah yang ditandai oleh kotornya wilayah perairan dan timbulnya bau menyengat.

Menurut hasil penelitian Gede (2007), limbah cair tahu mempunyai kandungan protein, lemak, dan karbohidrat atau senyawa-senyawa organik yang masih cukup tinggi. Jika senyawa-senyawa organik itu diuraikan baik secara aerob maupun anaerob akan menghasilkan gas metana (CH4), karbondioksida (CO2), gas-gas lain, dan air (BPPT, 1997). Gas metana merupakan bahan dasar pembuatan biogas. Biogas adalah gas pembusukan bahan organik oleh bakteri pada kondisi anaerob. Gas ini tidak berbau, tidak berwarna, dan sangat mudah terbakar. Biogas sebanyak $1000 \mathrm{ft}^{3}\left(28,32 \mathrm{~m}^{3}\right)$ mempunyai nilai pembakaran yang sama dengan galon (1 US gallon = 3,785 liter) butane atau 5,2 gallon gasolin (bensin) atau 4,6 gallon minyak diesel. Untuk memasak pada rumah 
tangga dengan 4-5 anggota keluarga cukup $150 \mathrm{ft}^{3}$ per hari (Goendi Sunarto, 2008). Limbah cair tahu mempunyai kandungan metana lebih dari $50 \%$, sehingga sangat memungkinkan sebagai bahan baku sumber energi biogas.

\section{Tinjauan Pustaka}

Limbah industri tahu terdiri dari dua jenis, yaitu limbah cair dan padat. Dari kedua jenis limbah tersebut, limbah cair merupakan bagian terbesar dengan perbandingan $7: 1$ dan berpotensi mencemari lingkungan. Dan ada dua karaktristik yaitu fisika dan kimia. Karaktristik fisika meliputi padatan total, suhu warna dan bau. Sedangkan karaktristik kimia meliputi bahan organic, bahan anorganik dan gas.

Limbah cair industri tahu juga mengandung bahan-bahan organic komplek yang tinggi terutama protein dan asam-asam amino dalam bentuk padatan tersuspensi maupun terlarut (EMDI - Bapedal, 1994). Adanya senyawa-senyawa organic tersebut menyebabkan limbah cair industri tahu rata-rata mengandung Biologycal Oxygen Demand (BOD) $4583 \mathrm{mg} / \mathrm{liter}$, Chemycal Oxygen Demand (COD) 7050 mg/liter dan Total Solid Suspension (TSS) $4743 \mathrm{mg} / \mathrm{liter}$ dan minyak atau lemak $26 \mathrm{mg} /$ liter yang tinggi (Tay, 1990; BPPT, 1997) yang apabila dibuang ke perairan tanpa pengolahan terlebih dahulu dapat menyebabkan pencemaran.

Biogas adalah produk akhir pencernaan atau degradasi anaerobic bahan-bahan organic oleh bakteribakteri anaerobic dalam lingkungan bebas oksigen atau udara. Komponen terbesar biogas adalah Methana $\left(\mathrm{CH}_{4}\right.$, $54-80 \%$ volume) dan karbodioksida $\left(\mathrm{CO}_{2}, 20-45 \%\right.$ volume $)$ serta sejumlah kecil $\mathrm{H}_{2}, \mathrm{~N}_{2}$ dan $\mathrm{H}_{2} \mathrm{~S}$. Berat jenis gas metana 0,554 , kelarutannya dalam air rendah, pada suhu $20{ }^{\circ} \mathrm{C}$ dan tekanan 1 atm. Gas metana termasuk gas yang stabil (BPPT, 1997).

Proses penguaraian oleh mikroorganisme untuk menguraikan bahan-bahan organik terjadi secara anaerob. Pada prinsipnya proses anaerob adalah proses biologi yang berlangsung pada kondisi tanpa oksigen oleh mikrooeganisme tertentu yang mampu mengubah senyawa organik menjadi metana (biogas). Secara umum, proses anaerob terdiri dari empat tahap yakni : hidrolisis, pembentukan asam, pembentukan asetat dan pembentukan metana. Proses anaerob dikendalikan oleh dua golongan mikroorganisme (hidrolitik dan metanogen) (BPPT, 1997).

Teknologi biogas pada dasarnya memanfaatkan proses pencernaan yang dilakukan oleh bakteri methanogen yang produknya berupa gas methana (CH4). Gas methana hasil pencernaan bakteri tersebut bisa mencapai $60 \%$ dari keseluruhan gas hasil reaktor biogas, sedangkan sisanya didominasi $\mathrm{CO} 2$. Bakteri ini bekerja dalam lingkungan yang tidak ada udara (anaerob), sehingga proses ini juga disebut sebagai pencernaan anaerob (anaerob digestion). Bakteri Metanogen adalah bakteri yang bertindak sesuai dengan metana (gas) bahan organik dan hasil dan gas-gas lain sedang dalam proses daur hidup perlengkapan mereka dalam satu kondisi anaerob (Siska,2010) 


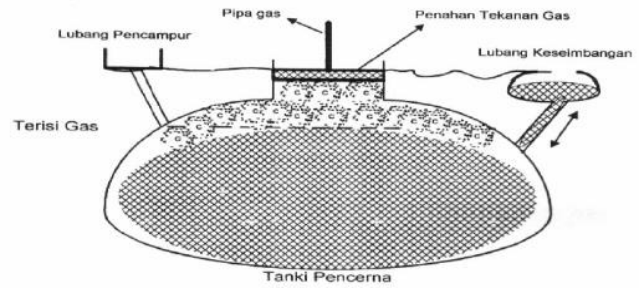

Gambar 1. Pencerna tipe Fixed Dome (China), (Syamsudin T.R., 2005)

\section{Tujuan Penelitian}

1. Untuk mengetahui berapa banyak biogas yang dapat dihasilkan terhadap limbah cair tahu yang digunakan dari fermentasi tersebut

2. Untuk mengetahui berapa lama waktu permentasi yang maksimum terhadap produktifitas biogas pada proses anaerob

3. Untuk mengetahui konstruksi dan bentuk reactor biogas yang efektif guna mendapatkan produksi biogas yang optimum

4. Untuk mengetahui karaktristik, mekanisme dan proses anaerob yang terjadi pada pengolahan limbah cair tahu

\section{Metode Penelitian}

Metode penelitian yang dilakukan adalah metode rekayasa yang merupakan suatu kegiatan rancang bangun, sehingga di dalamnya terdapat kontribusi baru, baik dalam bentuk proses maupun produk atau prototype. perancangan alat, pembuatan alat dan pengujian alat dengan limbah cair tahu. Alat yang digunakan drum plastic kapasitas 90 liter, Limbah tahu, ember, thermometer, manometer.

Proses fermentasi limbah cair tahu yaitu siapkan reaktor biogas, ukur kadar keasaman (ph) limbah cair tahu, masukkan limbah cair tahu tersebut ke dalam reaktor sebanyak 75 liter. Catat data-data ukuran seperti temperatur, tekanan biogas di dalam reaktor volume biogasnya. Pada hari ke 7 buang biogas yang ada di dalam reaktor, karena bercampur dengan udara, biogas tersebut tidak bagus, jika digunakan akan sulit terbakar dan suka terjadi ledakan gas jika bereaksi dengan oksigen. Setelah itu tutup kembali, lalu proses permentasi dilanjutkan lagi, pencatatan data diteruskan sampai tidak ada lagi penambahan volume biogas yang dihasilkan. Sekali-kali reaktor digoyang atau di aduk supaya terjadi penguraian limbah yang sempurnah dan gas yang terbentuk di bagian bawah naik ke atas. Setelah hari terakhir, tutup kran di reaktor lalu hubungkan saluran penampungan ke kompor gas untuk menguji biogas yang dihasilkan.

\section{Hasil Dan Pembahasan}

\section{Performansi Alat}

Alat penghasil biogas ini (reaktor) terbuat dari bahan plastik dimana tahan terhadap korosi karena akan selalu berhubungan dengan basa dari cairan limbah tahu dalam proses fermentasinya dengan waktu yang cukup lama. Alat reaktor ini terdiri atas dua bagian utama, yaitu:

$\square$ Bagian pencerna (reaktor) dan

$\square$ Bagian pengumpul gas

Alat penghasil biogas (reaktor) ini berkapasitas 90 liter bekerja dengan cara memasukkan bahan isian (cairan limbah tahu) sebanyak 75 liter, yang dalam hal ini terdapat rongga udara sebanyak 15 liter yaitu sebagai ruang proses fermentasi limbah cair tahu menjadi biogas. (Sadzali, 2010)

Pada lubang saluran pemasukan dan pengeluaran ditutup untuk mengkondisikan digester anaerob. Produksi gas hasil fermentasi anaerob oleh reaktor mulai pada hari ke-6. Gas 
yang dihasilkan dengan sendirinya mengalir ke plastik penampung gas. Volume plastik pengumpul dapat berkembang dengan semakin bertambahnya produk biogas dengan memanfaatkan tekanan biogas yang dihasilkan seiring dengan bertambahnya hari.

\section{Kualitas Biogas yang Dihasilkan}

a. Temperatur

Temperatur yang diukur pada penelitian ini ada dua, yaitu temperatur di dalam reaktor dan temperatur di luar reaktor, karena temperatur diluar atau temperatur lingkungan sangat mempengaruhi temperatur yang terjadi di dalam reaktro. Temperatur terukur yang bekerja pada reaktor menunjukkan pada angka 27 - $32{ }^{\circ} \mathrm{C}$ (seperti pada tabel 5.1. Temperatur hasil pengukuran), sesuai dengan temperatur yang diisyaratkan pada tahap perancangan.

b. $\mathrm{pH}$ (Derajat keasaman)

Derajat keasaman dari bahan limbah cair tahu di dalam reaktor merupakan salah satu indikator bagaimana kerja reaktor. Derajat keasaman dapat diukur dengan $\mathrm{pH}$ meter atau kertas $\mathrm{pH}$. Dan hasil pengukuran derajat keasaman $(\mathrm{pH})$ yang didapat 7,1. Ternyata masih dalam batas yang ideal yang di anjurkan 6,8 sampai 8, sehingga kwalitas biogas yang dihasilkan dapat lebih baik.
Tabel 1. Data pengukuran hasil penelitian

\begin{tabular}{|c|c|c|c|c|c|}
\hline $\begin{array}{c}\mathbf{N} \\
\mathbf{o .}\end{array}$ & $\begin{array}{c}\text { Ha } \\
\mathbf{r i} \\
\mathbf{k e}\end{array}$ & $\begin{array}{c}\text { Temper } \\
\text { atur } \\
\text { Ruang } \\
\left({ }^{\circ} \mathbf{C}\right)\end{array}$ & $\begin{array}{c}\text { Tepera } \\
\text { tur } \\
\text { Reakto } \\
\mathbf{r}\left({ }^{\mathbf{o}} \mathbf{C}\right)\end{array}$ & $\begin{array}{c}\text { Tekan } \\
\text { an } \\
\text { Reakt } \\
\text { or } \\
(\mathbf{k g} / \mathbf{c m} \\
\mathbf{2})\end{array}$ & $\begin{array}{c}\text { Volu } \\
\text { me } \\
\text { bioga } \\
\mathbf{S} \\
(\mathbf{l i t e r} \\
)\end{array}$ \\
\hline 1. & 2 & 27 & 27 & - & - \\
\hline 2. & 4 & 27 & 28 & - & - \\
\hline 3. & 6 & 29 & 30 & 0,07 & 1,85 \\
\hline 4. & 8 & 28 & 29 & 0.06 & 1,74 \\
\hline 5. & 10 & 30 & 31 & 0,12 & 4,36 \\
\hline 6. & 12 & 29 & 29 & 0,19 & 11,52 \\
\hline 7. & 14 & 30 & 30 & 0,26 & 20,37 \\
\hline 8 & 16 & 28 & 31 & 0,33 & 32,78 \\
\hline 9. & 18 & 29 & 29 & 0,48 & 44,10 \\
\hline 10 & 20 & 30 & 30 & 0,57 & 58,27 \\
. & & & & & \\
\hline 11 & 22 & 29 & 32 & 0,68 & 70,36 \\
. & & & & & \\
\hline 12 & 24 & 30 & 31 & 0,80 & 79,61 \\
\hline. & & & & & \\
\hline 13 & 26 & 29 & 31 & 0,89 & 81,83 \\
. & & & & & \\
\hline 14 & 28 & 31 & 32 & 0,91 & 82,04 \\
\hline
\end{tabular}

\section{c. Laju Pertumbuhan Biogas}

Gambar

5.1. dan

5.2. menunjukan bahwa, pada hari ke-1 sampai ke-5 belum ada aktivitas produksi biogas, ini terlihat tidak adanya kenaikan volume dan tekanan gas yang dihasilkan, atau ditandai dengan tidak mengembangnya pengumpul gas. Hal ini disebabkan oleh adanya proses pemasakan dan pengembangan bakteri di dalam reaktor. Kran reaktor dalam kondisi tetutup untuk menjaga agar tidak ada udara yang masuk.

Pada hari ke-6 gas mulai terbentuk yaitu dengan pengembangan volume pengumpul mulai terlihat sebesar 1,85 liter dan tekanan 0,07 $\mathrm{kg} / \mathrm{cm}^{2}$. Memasuki hari ke-7 Gas yang telah terkumpul dibuang terlebih dahulu karena masih mengandung udara untuk menghindari ledakan gas jika bereaksi dengan oksigen. Pada hari ke-8 Sampai hari ke-28 volume gas naik kembali 
hingga mencapai 82,04 liter pada tekanan $0,91 \mathrm{~kg} / \mathrm{cm}^{2}$.

Berdasarkan hasil penelitian yang didapat (Tabel 1) Volume biogas yang dihasilkan menunjukkan bahwa adanya peningkatan kenaikan yang cukup signifikan. Terlihat mulai hari ke 10 sampai hari ke 24 berbanding lurus. Hal ini menunjukan bahwa semakin lama proses fermentasi akan semakin banyak jumlahnya biogasnya. Memasuki hari ke 26 terlihat kecendrungan grafik mulai menurun, hingga terlihat jelas pada hari ke 28. Hal ini menunjukkan bahwa produktivitas limbah cair tahu untuk menghasilka biogas sudah tidak baik lagi.

Kemudian untuk peningkatan tekanan biogas juga demikian, terlihat ada kenaikan cukup jelas walau tidak begitu signifikan jika dibandingkan peningkatan pada volumenya, namun ini cukup berarti. Terlihat mulai hari ke 10 hingga hari ke 26, walau akhirnya terlihat grafik tidak naik lagi hingga hari ke 28.

Untuk perubahan temperatur biogas yang terjadi nampaknya sangat dipengaruhi oleh temperature udara di sekitar reactor atau temperature di luar reactor. Hal ini terlihat jelas perbandingan antara temperatur diluar reaktor dengan temperatur di dalam reactor. Perubahan temperatur yang terjadi terlihat fluktuatip yang tidak terlalu jauh, baik naiknya maupun turunya temperatur tersebut. Namun pada akhirnya terlihat bahwa teperatur yang terjadi lebih tinggi dibandingkan dengan teperatur awal-awal pada saat biogas mulai dimasukkan.

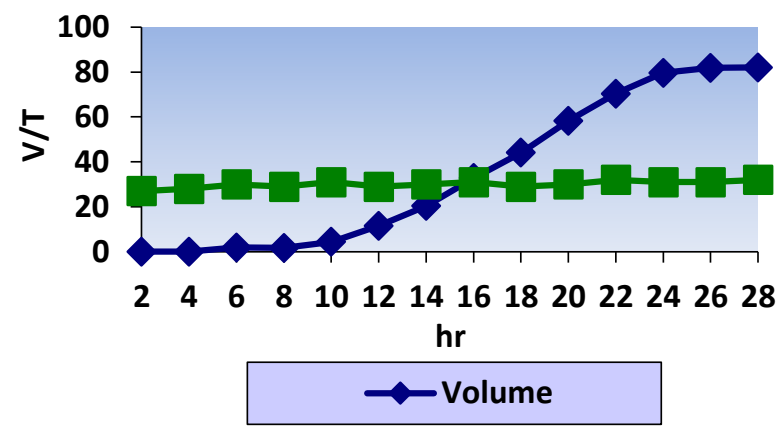

Gambar 2. Grafik perbandingan antara Volume dan Temperatur biogas terhadap jumlah hari.

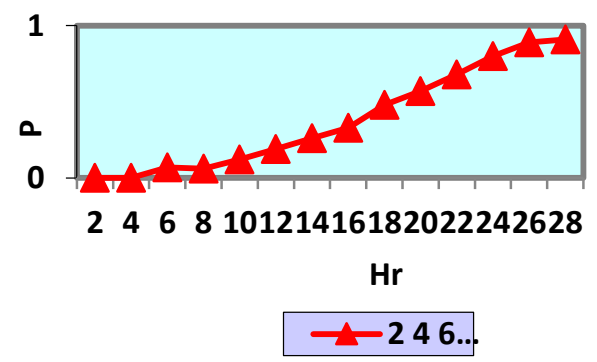

Gambar 3. Grafik perbandingan antara Tekanan biogas terhadap Jumlah hari

d. Pengadukan

Pengadukan dilakukan untuk mendapatkan campuran substrat yang homogen dengan ukuran partikel yang kecil. Pengadukan selama proses dekomposisi untuk mencegah terjadinya benda-benda mengapung pada

permukaan cairan dan berfungsi mencampur methanogen dengan substrat. Dan supaya terjadi penguraian limbah yang sempurnah dan gas yang terbentuk di bagian bawah naik ke atas. Pengadukan juga memberikan kondisi temperatur yang seragam dalam reaktor.

\section{Kapasitas Limbah Cair Tahu}

Pada satu industri rumahan tahu dan tempe di Desa Yosodadi Metro Timur Kota Metro berdasarkan identifikasi lapangan, kebutuhan kedelai 
mencapai $250 \mathrm{~kg} / \mathrm{hari}$. Jumlah tersebut diperoses untuk tempe sebanyak 50 $\mathrm{kg} / \mathrm{hari}$, sedang yang diproses untuk tahu sebanyak $200 \mathrm{~kg} / \mathrm{hari}$. Karena hanya limbah tahu yang dipakai, sebab lebih banyak menghasilkan gas methan ketimbang limbah tempe, maka kapasitas limbah cair yang dihasilkan dapat dihitung dengan :

Kapasitas Limbah cair $=$ Koefisien limbah x jumlah kedelai diolah $=9,46$ liter $/ \mathrm{kg} \times 200 \mathrm{~kg} / \mathrm{hari}$ $=1892$ liter/hari

Jadi kapasitas produksi limbah cair tahu mencapai $1,892 \mathrm{~m}^{3}$ /hari dari $200 \mathrm{~kg}$ kedelai terolah.

\section{Pemenuhan Kebutuhan Bahan Bakar}

Dengan pengolahan limbah cair tahu sebanyak 90 liter menghasilkan biogas sebanyak $0,08204 \mathrm{~m}^{3}$, maka jika limbah tahu yang sebanyak 1892 liter/hari diolah semua, maka akan menghasilkan biogas sebanyal 1,724 $\mathrm{m}^{3} /$ hari. Hal ini menunjukan bahwa pengolahan limbah cair tahu tersebut sangat cukup efektif jika diolah sebagai bahan bakar altenatif, apalagi di saat sekarang ini dimana bahan bakar cair dan bahan bakar kayu sudah sangat mahal dan langkah. Ditambah sekarang bahan bakar gas sudah mulai susah didapat untuk kondisi-kondisi tertentu seperti hari-hari besar keagamaan. Belum lagi jika nanti subsidi bahan bakar benar-benar akan dicabut oleh pemerintah, dan itu bahan bakar pasti akan sangat sulit didapat dan harganyapun akan sangat mahal sekali. Oleh karena itu mari kita terus menggalakan pemanfatan sumbersumber energi terbarukan, untuk mengatasi kesuliatan bahan bakar tersebut.

Berdasarkan penelitian Sadzali Imam (2010), Nilai kalor untuk biogas sekitar $4785 \mathrm{Kkal} / \mathrm{m} 3=4,785 \mathrm{kkal} /$ liter. Nilai kalor untuk LPG sekitar 10.882 $\mathrm{Kkal} / \mathrm{m} 3=10,882 \mathrm{kkal} /$ liter. Harga LPG $12 \mathrm{Kg}$ sekitar Rp. 85.000, volume jenis 500 liter $/ \mathrm{kg}=$ Rp.14.167/liter. Dan nilai kalori Minyak Tanah 9122 kkal/liter. Harga minyak tanah Rp. 9000/liter. Dengan menggunakan perbandingan dengan LPG dan minyak tanah, maka Harga Biogas = Nilai Kalor Biogas x Harga LPG(minyak tanah) : Nilai Kalor LPG(minyak tanah).

- Harga biogas terhadap LPG.

Harga biogas $=4,785 \mathrm{kkal} / \mathrm{l} \mathrm{x}$ Rp. $14,167 / 1$ : 10,882 kkal/ $1=$ Rp. 6,23/liter

- Harga biogas terhadap minyak tanah

Harga Biogas $=\quad 4,785 \mathrm{kkal} / 1$ x Rp. 9000/l : 9122kkal /1 = Rp. 4,72/liter

Berarti masih sangat murah harga bahan bakar biogas. Belum kita bandingkan dengan bahan bakar minyak atau bahan bakar kayu yang jelas-jelas tingkat efisiensinya dibawah LPG. Pastilah bahwa biogas merupakan bahan bakar yang cukup menjadi perhatian dimasa yang akan datang.

Dengan demikian bahwa limbah cair tahu tersebut dapat dimanfaatakan sebagai bahan bakar untuk proses pengolahan tahu dan juga kebutuhan energi untuk keperluan keluarga, sehingga industri tahu rumahan tidak perlu lagi kesulitan untuk membeli bahan bakar. Untuk kebutuhan energi untuk memasak bagi keluarga dengan anggota keluarga 4-5 orang, diperlukan 1,5 $\mathrm{m} 3 /$ hari. Sehingga biogas hasil fermentasi dari limbah cair tahu cukup untuk memenuhi beberapa kepala keluarga disekitar indutri tahu rumahan 
tersebut. Sehingga dapat menjadi satu lahan ekonomi baru selain tahu.

\section{Kesimpulan}

Setelah dari hasil dan pembahasan tadi, maka dapat diambil suatu kesimpulan dari penelitian ini, yaitu :

1. Dari 90 liter limbah cair tahu yang diolah maka akan didapat biogas sejumlah $0,08204 \mathrm{~m}^{3}$ atau 82,04 liter biogas

2. Berdasarkan hasil pengujian diketahui bahwa waktu fermentasi maksimum diketahui yaitu 28 hari

3. Tenyata bahwa untuk menapatkan proses fermentasi limbah cair tahu maka diperlukan konstruksi reaktor biogas yang tidak terlalu rumit (cukup sederhana) dan tidak harus kokoh serta bahan yang tidak harus mahal juga tidak terlalu berbahaya. Kita sudah dapat mengolah dan menghasilkan biogas untuk bahan bakar.

4. Dan ternyata memang untuk mendapatkan hasil yang maksimal dari proses anaerobik ini, diperlukan beberapa perlakuaan tersendiri, seperti temperatur sebaiknya di jaga jangan sampai melebihi atau di bawah dari temperatur yang diisaratkan. Kemudian limbahnya harus selalu diaduk agar reaksi limbahnya akan selalu terurai. Kemudian bahan limbah cair tahunya juga harus yang baik.

\section{Saran}

Dari hasil penelitian yang telah dilakukan, maka disarankan kiranya perlu dilakukan pengujian dengan menggunakan bahan tambah starter dari bahan tertentu seperti biji asam jawa, kulit jeruk yang dapat mempercepat proses fermentasi, sehingga waktu yang diperlukan dapat lebih singkat.

Juga diharapkan air limbah sisa mencuci kedelai dan air sisa mencuci alat-alat pembuatan tahu juga digunakan, untuk meminimal terjadinya pencemaran, walaupun memang kwalitas limbahnya kurang baik.

\section{Daftar Pustaka}

[I] Bappeda Medan, 1994, Penelitian Pencemaran Air Limbah Di Sentra Industri kecil Tahu/ Tempe di Kec. Medan Tuntungan Kotamadya Dati II Medan, Laporan Penelitian, Bappeda TK II Medan, Medan.

[II] BPPT, 1997a, Teknologi Pengolahan Limbah Tahu-Tempe Dengan Proses biofilter Anaerob dan

http://www.enviro.bppt.go.id (diakses 24 september 2008)

[III] Gede Sudaryanti N L, dkk, 2007, Pemanfaatan Sedimen Perairan Tercemar Sebagai Bahan Lumpur Aktif Dalam Pengolahan Limbah Cair Industri Tahu, Laporan Penelitian, Universitas Udayana Bali.

[1V] Goendi Sunarto, Purwadi tri dan Prima Nugroho, Andri, November 2008, Kajian model digester limbah cair tahu Untuk produksi biogas berdasrkan waktu penguraian, Disampaika pada seminar nasional Teknik Pertanian 2008 di Jurusan Teknik Pertanian Fakultas Teknologi Pertanian 
UGM, Yogyakarta 18-19

November 2008.

[V] Rahayu sugi, Purwaningsih Dyah, Pujianto (2009) pemanfaatan kotoran ternak sapi Sebagai sumber energi alternatif ramah Lingkungan beserta aspek sosio kulturalnya, Jurnal Inotek, Volume 13, Nomor 2, Agustus 2009 FISE Universitas Negeri Yogyakarta.

[VI] Sadzali Iman, Desember (2010), potensi limbah tahu sebagai biogas, Jurnal UI Untuk Bangsa Seri Kesehatan, Sains, dan Teknologi, Volume 1, Desember 2010.

[VII] Siska Rosilawati Siallagan, Nurmay (2010), Pengaruh waktu tinggal dan komposisi bahan baku Pada proses fermentasi limbah cair industri tahu terhadap produksi biogas, Tesis, Universitas Sumatera Utara, Medan.

[VIII] Syamsuddin, T.R, dkk. 2005, Bahan Bakar Alternatif Asal Ternak, Sinar Tani, Edisi 21-27 Desember 2005, No 3129 Tahun XXXVL. 